\title{
Cross breeding of different domesticated lines as a simple way for genetic improvement in small aquaculture industries: Heterosis and inbreeding effects on growth and survival rates of the Pacific blue shrimp Penaeus (Litopenaeus) stylirostris
}

\author{
Emmanuel Goyard ${ }^{\mathrm{a},}{ }^{*}$, Cyrille Goarant ${ }^{\mathrm{a}}$, Dominique Ansquer ${ }^{\mathrm{a}}$, Pierre Brun ${ }^{\mathrm{a}}$, Sophie de \\ Decker $^{a}$, Robert Dufour ${ }^{a}$, Christian Galinié ${ }^{b}$, Jean-Marie Peignon ${ }^{a}$, Dominique Pham ${ }^{a}$, Elodie \\ Vourey $^{b}$, Yves Harache ${ }^{a}$ and Jacques Patrois ${ }^{a}$ \\ a Ifremer, Département Aquaculture en Calédonie, Station de Saint Vincent, BP 2059, 98846 Nouméa, New \\ Caledonia

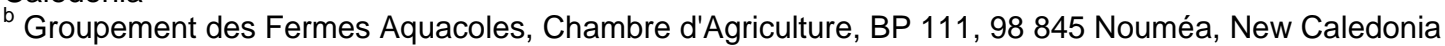

*: Corresponding author : E. Goyard, email address : Emmanuel.Goyard@ifremer.fr

\begin{abstract}
:
Two populations of the Latin American shrimp Penaeus (Litopenaeus) stylirostris domesticated in Hawaii and in New Caledonia were previously shown to be genetically differentiated and proven highly inbred. In New Caledonia, where different Vibriosis affect shrimp production and antibiotic use is banned in growing ponds, the Hawaiian population was introduced to increase the allelic variability available for local shrimp farmers and start a genetic improvement program. Growth and survival rates of the two pure populations and the two-way F1-hybrids obtained by breeding Hawaiian animals with New Caledonian animals were assessed in several simple experiments (earthen ponds, floating cages and experimental infection challenges) during two years on two successive generations. Results were very consistent: F1-hybrids growth rates in earthen ponds were $37 \%( \pm 7 \%$ SD) higher than for pure populations. Cage experiments demonstrated no competition between the different populations when reared together or separately in a common environment. The F1-hybrids also showed better survival rates in all experiments. Combining the results on growth and survival rates leads to the conclusion that biomass production is much higher with F1-hybrid populations than with pure populations using the same quantity of juveniles stocked: biomass production in ponds was increased 1.4 and 2.3 times on year 1 and year 2 respectively, and 1.9 times in floating cages. The advantage of growing F1hybrids appeared proportionally higher when environmental and sanitary conditions led to poorer survival (34\% in year 2 vs. $56 \%$ in year 1$)$.

These results are a good example of performance improvement by heterosis effect and/or of performance loss due to inbreeding in the pure populations. This study demonstrates that aquaculture industries which cannot afford large selection programs may benefit from using two different inbred parental stocks to produce F1-hybrids for each commercial growout. This is notably true when only inbred populations are available, or when introduction of genetic variability from the wild or from other genetic resources represents a zoo-sanitary risk. In our case, the expected increase in L. stylirostris production could be around 85\% (according to our average results) if producers keep stocking their ponds at their current densities using F1-hybrids. However, for sustainability reasons, it is advisable to stock F1-hybrid animals at lower densities, the gain in performance allowing producing the same amount of biomass with less input.
\end{abstract}

Keywords: Genetic improvement; Cross breeding; Shrimp; Penaeus (Litopenaeus) stylirostris; Growth; Survival; Vibriosis 


\section{Introduction}

During the second part of the $20^{\text {th }}$ century, genetics allowed large improvements in agricultural industries (poultry for example). Aquaculture could benefit from the use of such methodologies as well (Gjedrem, 1997; Argue and Alcivar-Warren, 2000.). Because domestication in modern aquaculture is still recent and not fully achieved, the aquacultured animals are not totally adapted to rearing conditions yet: therefore the benefits of genetics in aquaculture could be even higher than in traditional agriculture. Many experimental genetic improvement programs have been developed during the past 10-15 years at different levels and in different parts of the world for molluscs, finfishes and crustaceans (Gjøen and Bentsen, 1997; Moss, 2002). They all aim at helping aquaculture industries to be competitive and sustainable in their own socio-economical and bio-technical contexts. But a genetic improvement strategy which proved to be efficient in a given context on a given biological model is not necessarily efficient in another context.

The R\&D programs on domestication and selection of the white shrimp Penaeus (Litopenaeus) vannamei during the last decade were implemented to support the growing industry exploiting this species in its natural distribution area (Central and South America). For this species, some selective breeding programs are locally developed (Gitterle et al., 2005). Some others are managed abroad using "specific pathogen-free (SPF)" animals from the United States Marine Shrimp Farming Program (USMSFP). This program promotes a strategy which reduces the zoosanitary risk linked to international transfers and improves grow-out results (Lotz et al., 1995; Moss et al., 2005a). Several shrimp lines selected for their resistance to pathogens or for their growth rates are now commercially available and certified free of the four following viruses: Taura Syndrome Virus, Infectious Hypodermal and Hematopoietic Necrosis Virus, White Spot Syndrome Virus, and Yellow Head Virus, (Moss et al., 2005b). This has induced the recent shift of many Asian shrimp industries from the local giant tiger prawn Penaeus monodon (for which domestication is just starting) to $P$. vannamei (Rosenberry, 2006). As a consequence, the global production of $P$. vannamei reached 1509000 tons in 2005 (+435\% compared to 2001), a 60\% share of the global aquaculture shrimp production, exceeding, the 723000 tons production of $P$. monodon (+8\% compared to 2001), (FAO, 2007). As a result, the outputs of research for $L$. vannamei are more likely transferred than for species like Marsupenaeus (Penaeus) japonicus and P. stylirostris which have smaller productions (around $2.8 \%$ and $0.1 \%$ of the global production, respectively) divided in micro-industries in different countries.

Developing genetic improvement programs for these species of low global economic weight is even more difficult since (i) the efficiency of any selective breeding program is linked to the level of genetic variability available in the population under selection and (ii) some of the producing countries, which have introduced and domesticated such species, sometimes with very little genetic care, have no direct access to the wild genetic resources. Indeed genetic variability loss in such hatchery-propagated aquaculture species has been shown, notably in shrimp populations: Sbordoni et al. (1986) pointed out the reduction of heterozygosity in hatchery stocks of $M$. japonicus. Bierne et al. (2000) observed low levels of allelic diversity in the Tahitian stock of $P$. stylirostris which is known to be based on a restricted number of founders at the beginning of their domestication (Michel, pers. com.), when the control of the reproduction was not fully mastered (AQUACOP, 1983). Goyard et al. (2003) have shown that different domesticated stocks of $P$. stylirostris in Tahiti, New Caledonia and Hawaii had lost $85-90 \%$ of the allelic variability available in the wild. In addition, the negative impact of inbreeding on the capacity to adapt to new rearing conditions were demonstrated for $P$. vannamei by De Freitas and Junior (2002). Bierne et al. (2000) also found that the most inbred individuals within the Tahitian $P$. stylirostris population had the poorest growth performances.

In the industries based on captive exotic species of low global economic weight, reintroduction of genetic variability in the broodstocks to initiate genetic improvement programs from larger genetic bases is highly recommended. It may be difficult to implement because of the risks to introduce wild animals with exotic pathogens from the natural distribution area (Moss, com. pers.; Goyard and Goguenheim, unpublished data). The use of genetically different domesticated stocks with a proven safer zoosanitary status may represent an interesting option to lower inbreeding and increase allelic variability. But if the newly re-introduced genetic variability is also low, the management of the new composite population may be difficult and quickly lead to more inbreeding, as the total number of founders of the composite population will still be low. This is why keeping two genetically different populations as separated broodstocks and producing two-way intraspecific hybrids can be considered as an alternative to selective breeding among one unique composite population. This strategy may induce a heterosis effect. At the least the $F_{1}$-hybrids would not suffer from any inbreeding, their parents being unrelated. Even if each parent is inbred they may benefit from the purging of the genetic load of the species which has likely occurred during the domestication process within the two separate stocks. However, to the best of our knowledge, this strategy has never been tested in shrimp aquaculture.

The shrimp industry in New Caledonia is based on a $P$. stylirostris population which has lost most of the allelic variability available in the wild populations (Goyard et al., 2003). It demonstrates high productivity (Lucien-Brun, 2001) although it has been affected by two distinct diseases caused by pathogenic vibrios in specific environmental conditions. First, a septicaemic vibriosis by Vibrio penaeicida affects all the farms when the rearing pond temperatures fall at the beginning of the cool season. This disease is known as "Syndrome 93" (Mermoud et al., 
1998; Goarant et al., 1999). More recently, another septicaemic vibriosis by a highly pathogenic Vibrio nigripulchritudo strain has been affecting a few farms in the hot season, a disease known as "Summer Syndrome" (Goarant et al., 2006). Whether these seasonal mortalities are related to a lack of resistance linked to the high inbreeding of the New Caledonian P. stylirostris population is not documented. This question has been integrated in a multidisciplinary research project developed by Ifremer in New Caledonia and called DESANS (French acronym for Stylirostris Health Challenge) (Goarant et al, 2004a; Harache and Herbland, 2004).

In the present paper, we compare under several experimental conditions the growth and survival rates of different populations of $P$. stylirostris. The first populations are composed of animals domesticated in New Caledonia. The second populations are made of animals domesticated in Hawaii. They are genetically different from the first ones (Goyard et al., 2003) and were recently introduced in New Caledonia. The last populations are made of two way hybrids $\left(F_{1}\right)$ obtained by breeding Hawaiian animals with New Caledonian animals. The experiments were conducted during two years on two successive generations. By doing so, we assess for the first time the benefits that small aquaculture industries based on a non-indigenous species could draw from developing simple crossbreeding programs to improve their production.

\section{Materials and methods}

\subsection{Stocks, populations and animals used in all experiments}

The genetic diversity of the New Caledonian stock was described using microsatellite markers (Goyard et al., 2003). This stock was introduced several times from 1976 to 1980 in New Caledonia via Tahiti from Latin America (AQUACOP, 1979). It was then reproduced in captivity every 8-12 months from animals reared in earthen ponds. It had been domesticated for at least 35 generations by the end of 2005; severe bottle necks occurred during domestication and the resulting number of effective founders was estimated between 2 and 4 for this population (Goyard et al., 2003). The animals used in this study belonged to two successive generations of this stock, born in 2005 and 2006, referenced CC-2005 and CC-2006 and structured in 12 and 20 biparental families (with no half-sib families), respectively.

The genetic characteristics of the Hawaiian stock used in this study were also described using microsatellite markers (Goyard et al., 2003). The stock was introduced in Hawaii from Ecuador in 1995 and confirmed "SPF" in the summer of 1996 (Brock, pers. Com.). It was then domesticated in an indoor controlled environment to keep its "SPF" status. The number of effective founders used was estimated between 2 and 9 for this population (Goyard et al., 2003). Juveniles of the $8^{\text {th }}$ generation of domestication, referenced $\mathrm{HH}-2004$ and structured in 16 biparental families, were finally introduced in New Caledonia in 2005 (Wyban pers. com). The stock was then reproduced at the end of 2005 and 2006 to produce two successive generations, born in 2005 and 2006, referenced HH-2005 and $\mathrm{HH}-2006$ and structured in 16 and 11 biparental families (with no half-sib families) respectively.

In parallel, New Caledonian and Hawaiian adults belonging to the CC-2004 and to the $\mathrm{HH}-2004$, respectively, were used in 2005 to produce a two-way hybrid population structured in 11 biparental families (with no half-sib families) and referred to as $F_{1}-2005$. Similarly, New Caledonian CC-2005 and Hawaiian HH-2005 adults were used in 2006 to produce a two-way hybrid population structured in 14 biparental families and referenced $\mathrm{F}_{1}-2006$.

The populations CC-2005, HH-2005 and $\mathrm{F}_{1}-2005$ were all produced simultaneously in the same hatchery. They were then reared separately in earthen ponds for 48 days until their mean individual weight reached $3.3 \mathrm{~g}$ $(\mathrm{SD}=0.8 \mathrm{~g}), 3.4 \mathrm{~g}(\mathrm{SD}=1.3 \mathrm{~g})$ and $2.9 \mathrm{~g}(\mathrm{SD}=0.4 \mathrm{~g})$, respectively. Then they were tagged by injection of coloured elastomer (Godin et al, 1996) and dispatched for experiments as described below. The differences in initial individual weights were not significant between CC-2005 and HH-2005 $(P>0.10)$, but animals of $\mathrm{F}_{1}-2005$ were significantly lighter than the others $(P<0.01)$.

The same protocol was applied to the populations CC-2006, $\mathrm{HH}-2006$ and $\mathrm{F}_{1}-2006$ with mean weights of $4.0 \mathrm{~g}$ $(\mathrm{SD}=1.2 \mathrm{~g}), 11.1 \mathrm{~g}(\mathrm{SD}=2.9 \mathrm{~g})$ and $3.8 \mathrm{~g}(\mathrm{SD}=1.2 \mathrm{~g})$ respectively at the time of tagging after 63 days of nursing The differences in mean weight were not significant between CC-2006 and F1-2006 $(P>0.10)$ but the animals of $\mathrm{HH}$ 2006 were significantly heavier than the others $(P<0.01)$ due to lower densities induced by poorer survival rates observed in their rearing pond during the nursing period. 


\subsection{Experiments in earthen ponds exposed to the risk of Syndrome 93 caused by V. penaeicida}

To test the in situ resistance to Syndrome 93 occurring in winter and caused by $V$. penaeicida, two $500 \mathrm{~m}^{2}$ earthen ponds of the Ifremer research station of New Caledonia were stocked in the middle of the warm season of each year of testing using the animals described above in "communal rearing" conditions. The rearing density used in these experiments were 20 animals par square meter. Ponds were then managed like regular production ponds (Clifford, 1992; Della Patrona et al., unpublished.): a commercial feed pellet was distributed daily and rations were adjusted to animal growth assessed by sampling every 2-3 weeks; water renewal depended on water column characteristics.

Ponds were harvested after the beginning of the cold season, 134 and 126 days after stocking in 2005 (populations CC-2005, HH-2005 and $F_{1}-2005$ ) and 2006 (populations CC-2006, HH-2006 and $\mathrm{F}_{1}-2006$ ), respectively. The surviving animals of each population were individually counted, sampled and weighed to assess precisely growth and survival rates.

\subsection{Experimental infection challenges}

Each year of testing, an earthen pond was stocked with tagged animals and managed as described before. It was used to provide controlled infection experiments with animals reared in the same environment, before any winter disease outbreak could apply selective pressure on the populations.

Tagged animals of the different populations to be tested were captured at least three weeks after stocking this pond. Depending on the challenge (see Table 1), 168 to 420 animals per population were counted, transferred, distributed and mixed in sixteen to thirty-two 200-liter tanks of an infection laboratory where they were kept for one week in filtered aerated seawater. Then the animals of all the tanks except two were either infected by immersion or injection with V. penaeicida strain AM 101 (Costa et al., 1998) as described by Saulnier et al. (2000a and 2000b) and de Lorgeril et al. (2004). The infection doses were estimated using a spectrophotometric reading at $600 \mathrm{~nm}$ of an overnight culture, and compared to a reference curve previously determined (data not shown). The actual infection doses were then assessed by plating serial dilutions of the bacterial culture on Marine Agar plates in triplicate. Concentrations of $5.10^{4}$ to $15.10^{4} \mathrm{~V}$. penaeicida CFU/ml of water were used for infections by immersion and 120-240 V. penaeicida CFU/animal were used for infections by injection. The animals of the two tanks which had not been infected were processed similarly but injected with sterile culture medium to be used as control animals.

Dead animals were removed 3-4 times a day and moribund animals checked for pathogens. The final count was made 3-7 days post-infection, depending on the mortality observed, no significant mortality occurring after the epizootic phase of the experimentally-induced disease (Saulnier et al., 2000a, b; Goarant et al., 2004b). A total of three challenges were run on each year-class (Table 1).

\subsection{Experiments in floating cages during a Summer Syndrome outbreak caused by V. nigripulchritudo}

During the second year of testing, a 6 ha production pond in a commercial farm affected by the summer disease linked to V. nigripulchritudo (Goarant et al., 2006) was seeded with a commercial batch of New Caledonian postlarvae. This pond was considered as an environment prone to induce the onset of the summer disease, which effectively broke out later (Della Patrona et al., unpublished).

Thirty $8 \mathrm{~m}^{3}$ (1-m deep) floating cages as described by Chim et al. (2007) were installed in this pond and stocked with nursed animals of populations CC-2006, $\mathrm{HH}-2006$ and $\mathrm{F}_{1}-2006$ as described before. Two conditions of testing were used to assess the possible impacts of competition on growth and survival rates of these populations (Table 2): in nine cages, animals of the different populations were tagged and mixed together as in pond trials ("communal rearing" condition); in twenty-one other cages populations CC-2006 and $F_{1}-2006$ were reared separately ("separate rearing" condition). As explained in part 2.1, poorer survival rates of $\mathrm{HH}-2006$ during nursing period did not allow to test HH-2006 in "separate rearing" conditions. Initial densities are described in Table 2. Mean weights at seeding were $3.1 \mathrm{~g}(\mathrm{SD}=1.1 \mathrm{~g}), 9.7 \mathrm{~g}(\mathrm{SD}=1.6 \mathrm{~g})$ and $3.1 \mathrm{~g}(\mathrm{SD}=1.0 \mathrm{~g})$ for populations $\mathrm{CC}-2006, \mathrm{HH}-2006$ and $\mathrm{F}_{1}-2006$ respectively. Differences in individual weights were not significant between CC-2006 and $F_{1}-2006(P>0.10)$ but the animals of $\mathrm{HH}-2006$ were significantly heavier than the others $(P<0.01)$ due to lower densities and poorer survival rates observed in their nursing pond. Animals were fed a commercial pellet at the feeding rate of $4-5 \%$ for 29,57 or 77 days (Table 2), and then individually counted, sampled and weighed.

In addition, $V$. nigripulchritudo prevalence and haemolymph concentration (number of presumed $V$. nigripulchritudo colonies per $10 \mu \mathrm{l}$ of haemolymph) were assessed in three cages 29,57 and 77 days after stocking by sampling the haemolymph of 30 animals per population using the techniques and criteria described by Goarant et al. (2006). Six classes of $V$. nigripulchritudo concentration were considered $(0 ; 1-10 ; 11-50 ; 51-100 ; 101-300 ;>300$ colonies of $V$. nigripulchritudo per $10 \mu \mathrm{l}$ of haemolymph) and the percentage of animals belonging to each class was calculated. 


\subsection{Statistical analysis}

ANOVA and Fisher tests for pair wise comparison were performed to compare weights between the populations tested. Chi-square tests performed on final counts in ponds and infection experiments were made to compare survival rates of the different populations

ANOVA performed on survival rates transformed by $\operatorname{Arcsin}(\sqrt{ } x)$ were used to analyse survival rates in cages of the different populations and to test for interaction between population and conditions of testing ("communal rearing" vs. "separate rearing") .

Chi-square tests performed on the number of animals belonging to each class of concentration of $V$. nigripulchritudo were made to analyse differences of carriage of the pathogen in the populations tested.

\section{Results}

\subsection{Survival and growth rate in earthen growout ponds exposed to Syndrome 93}

Overall survival rates were significantly higher for $F_{1}$-hybrids than for New Caledonian populations each year of testing (Table $1-P<0.01)$. $F_{1}$-hybrid survival rate was also higher than the Hawaiian population survival rate on the second year of testing (Table 1; $P<0.01$ ). The mortalities could not be directly linked to $V$. penaeicida because no moribund shrimp could be found and analyzed during the period, but the data typically fits Syndrome 93 mortality observed after sudden temperature drops (data not shown).

Growth curves observed for the different populations reared in ponds are given in Figures $1 \mathrm{a}$ and $1 \mathrm{~b}$. Both years of testing, $F_{1}$-hybrid final weights were significantly higher than New Caledonian and Hawaiian population final weights (Table 3; $P<0.001$ ). Taking into account the length of the experiments and the initial weight at the time of tagging and mixing, the average growth rates observed in these ponds were $0.16 \mathrm{~g} / \mathrm{day}, 0.16 \mathrm{~g} / \mathrm{day}$ and $0.21 \mathrm{~g} / \mathrm{day}$ for populations CC-2005, $\mathrm{HH}-2005$ and $\mathrm{F}_{1}-2005$, respectively, and $0.17 \mathrm{~g} / \mathrm{day}, 0.17 \mathrm{~g} / \mathrm{day}$ and $0.24 \mathrm{~g} / \mathrm{day}$ for populations $\mathrm{CC}-2006, \mathrm{HH}-2006$ and $\mathrm{F}_{1}-2006$, respectively (Table 3 ).

\subsection{Survival to infection challenges}

Mortalities in control non infected animals was lower in all experiment (data not shown) and mortalities in infected animals occurred in all experiments, but could not always be related to the pathogen used for infection, whether by immersion or injection. Unexpected septicaemia caused by indigenous $V$. nigripulchritudo was observed after animal transfer to the infection laboratory. A persistent contamination with $V$. nigripulchritudo lasted throughout the experimental infection with $V$. penaeicida (Table 1 ). This was particularly true during the second year of testing.

Survival rates of the animals one week after transfer into the infection laboratory (before experimental challenge) and final survival rates (after infection with $V$. penaeicida) were higher for $F_{1}$-hybrids than for the two other populations tested in each of the six experiments (Table 1). On average, $F_{1}-2005$ animal survival after transfer and infection was 57\% which was significantly higher than CC-2005 and $\mathrm{HH}-2005$ survival ( $50 \%$ and $47 \%$, respectively). Similarly, on average, $F_{1}-2006$ animal survival after transfer and infection, which was $6.3 \%$, showed a tendency to be higher than the "pure populations" CC-2006 and HH-2006 survival pooled together which was $2.4 \%$.

\subsection{Survival and growth rates in floating cages during "Summer syndrome" caused by V. nigripulchritudo}

Growth and survival of the populations reared in different conditions, as described in part 2.4, are given in Figure $2 \mathrm{a}$ and $2 b$.

No significant statistical interaction between rearing conditions (communal vs. separate rearing) and the populations (CC-2006 vs. $F_{1}$-2006) was observed neither for final weights nor for final survivals $(P>0.10)$. Final weights were significantly higher by $1.3 \mathrm{~g}$ in populations reared in competition than in populations reared alone out of competition $(P<0.001)$. No significant difference in survival rates was found between conditions of testing $(P>0.10)$.

$F_{1}$-hybrid final weights were significantly higher than New-Caledonian final weights in both conditions of testing (Table $3-P<0.001$ ). However they were not significantly different from the Hawaiian population reared in competition despite the initial differences of weights (Table $3-P>0.10$ ). Taking into account the length of the experiment and the initial weights of each population at the time of tagging and mixing (see part 2.1), the average growth rates observed in competition were $0.19 \mathrm{~g} /$ day, $0.19 \mathrm{~g} /$ day and $0.28 \mathrm{~g} /$ day for populations $\mathrm{CC}-2006, \mathrm{HH}-2006$ 
and $F_{1}-2006$, respectively, and those observed out of competition were $0.17 \mathrm{~g} /$ day and $0.26 \mathrm{~g} /$ day for populations CC-2006 and $F_{1}-2006$, respectively.

Overall survival rates of $F_{1}$-hybrids (52\%) were higher than Hawaiian (40\%) and New Caledonian (41\%) survival rates (Table 1; $P<0.05$ and $P<0.01$, respectively)

\subsection{Prevalence and V. nigripulchritudo haemolymph concentration in floating cages}

V. nigripulchritudo prevalence decreased from $96 \%$ at day 29 to $51 \%$ and $59 \%$ at day 57 and day 77 , respectively (mortality due to $V$. nigripulchritudo was first observed on day 29 in the pond where the cages were managed Della Patrona et al., unpublished). No significant difference in prevalence was detected between the three populations tested (Table 4; Chi-square test, $P>0.10$ ), but significant differences appear in terms of $V$. nigripulchritudo concentration: on day 29, animals belonging to CC-2006 carried more pathogens in their haemolymph than the others (Table $4 ; P<0.01$ ).

\section{Discussion}

Keys et al. (2004) have shown that inbreeding in the shrimp M. japonicus can reduce performances in terms of growth, survival and biomass production. They used experimental populations domesticated for few generations in conditions where spontaneous selection could still have occurred. Crnokrak and Barretta (2002) have reviewed data which demonstrate that the genetic load of species may be purged after several generations, the number of generations needed being variable. In the present study, we used populations domesticated for many generations and known to be inbred (Goyard et al., 2003). After 9-10 and 35-36 generations of domestication respectively, the Hawaiian and New Caledonian populations of $P$. stylirostris have likely purged their genetic load, at least partially, as they perform well in ponds (Lucien-Brun, 2001) or in tanks (Wyban, pers. com.) when there are no pathogens. These two distinct domesticated populations of $P$. stylirostris represented a very interesting genetic basis to obtain data to discuss the efficiency of crossbreeding as a genetic improvement strategy in aquaculture. Our results were obtained in different experimental conditions, it was thus necessary to combine them to analyze three main zootechnical parameters: growth rate, survival rate and biomass production (as a result of the first two).

In our pond experiments, mean individual weights of $F_{1}$-hybrid populations were significantly lower than the ones of pure Caledonian and pure Hawaiian populations at stocking (up to three times lower if we compare $\mathrm{F}_{1}-2006$ to $\mathrm{HH}$ 2006). Despite this fact, $F_{1}$-hybrids grew so fast that their final weight was higher than the others' (in ponds, year 1 and 2), or at least the equivalent of the initially heavier population (in cages, year 2, 2006). In fact, average growth rates which take into account initial weights and the length of the experiments in earthen ponds (Table 3 ) were consistent and not highly variable: $F_{1}$-hybrids growth rates in earthen ponds were $37 \%( \pm 7 \% \mathrm{SD})$ higher than the two pure populations' growth rates (Figure 3). These results were confirmed by the cage experiment in which growth rates were similar to the ones obtained in ponds (Table 3 and Figure 3). Additionally, the cage experiment showed that the difference in growth rates was not the consequence of any competition phenomenon between the different populations reared together: indeed there was no statistical interaction between the populations tested and the two conditions of testing (communal vs. separate rearing) in the cage experiment. In other words, $\mathrm{F}_{1}$-hybrids are fast growers independently of their rearing conditions.

In terms of survival rates, the interpretation of the results was more complex. During year 1 , when survival rates of the two pure populations was $56 \%$ in average, the average survival rate of $F_{1}-2005(61 \%)$ corresponded to a $9 \%$ increase of the final number of surviving animals for a same quantity of animals stocked. During year 2 , when survival rates of the two pure populations was only $34 \%$, the average survival rate of $F_{1}-2006(54 \%)$, corresponded to an increase of the final number of surviving animals of $60 \%$ for a same quantity of animals stocked (Figure 3 ). In these two pond experiments, the mortality observed occurred mainly when temperature dropped, which is typical of the winter disease "Syndrome 93" caused by V. penaeicida (Mermoud et al., 1998). However, as no moribund shrimp could be analysed, it is only possible to conclude that these field trials suggest that $F_{1}$-hybrids are more resistant to stress and/or pathogens than pure populations. The advantage of using $F_{1}$-hybrids is higher when the environmental conditions are worse and lead to poorer survivals. The results obtained in floating cages exposed to pathogenic $V$. nigripulchritudo are intermediate but consistent with the results obtained in experimental earthen ponds: while survival rates of the two pure populations reared together was $42 \%$ in average, the survival rate of $F_{1^{-}}$ $2005(52 \%)$, corresponded to a $24 \%$ increase of the final number of surviving animals for a same quantity of animals stocked (Figure 3).

Experimental infections could not demonstrate any specific resistance to a given pathogen as both pathogens, $V$. penaeicida and $V$. nigripulchritudo have likely interacted in most experiments. The only possible conclusion is a better global resistance to combined handling stress and pathogenic Vibrio in the $F_{1}$-hybrids. Survival rates obtained in experimental infection challenges during year 1 are also consistent with the differences observed in ponds the 
same year: when survival rates of the two pure populations in the infection laboratory was $49 \%$ on average, the survival rate of $\mathrm{F}_{1}-2005$ ( $57 \%$ on average), corresponded to a $18 \%$ increase of the final number of surviving animals for a same quantity of animals handled and infected. During year 2, the survival rates were very low in the infection laboratory and may be the result of the interaction of the two pathogenic Vibrio species. This was the first time in our research facilities that mortality due to indigenous $V$. nigripulchritudo was observed after handling. (Goarant, pers. com.): the survival rate in the infection laboratory of the two pure populations was $2 \%$ on average, while the survival rate of $F_{1}-2006$ was three times higher, which would suggest again that the relative advantage of the $F_{1^{-}}$ hybrids is higher when the conditions are worse. At last, the $V$. nigripulchritudo haemolymph concentration was significantly higher in the New Caledonian population than in the other two at day 29 of the cage experiment, when mortality occurred in the pond with the cages. This fact suggests that $F_{1}$-hybrids resist infection by pathogenic $V$. nigripulchritudo bacteria more efficiently than the New Caledonian animals. This could explain partly their higher survival rates. Further investigations are needed to conclude on that particular point.

Combining the results on growth and survival rates leads to the conclusion that biomass production is much higher with $F_{1}$-hybrid populations than with pure populations for the same quantity of juveniles stocked (Figure 3): biomass production in ponds was increased by factors of 1.4 and 2.3 in year 1 and year 2 respectively, and by a factor of 1.9 in floating cages. The advantage of hybrids appears higher when the survival of pure populations is lower. Pure population average survival in ponds was $56 \%$ on year 1 and only $34 \%$ on year 2 , the cage results being intermediate.

\section{Conclusion}

The fact that the hybrids of these two particular populations demonstrate higher growth rates, higher survival rates and, as a result, higher biomass production, may be a good example of performance improvement by an heterosis effect and/or, on the contrary, of performance losses in the pure populations attributable to inbreeding effects. Determining which of these two effects is predominant in our study is not easy, especially because wild animals are not available in New Caledonia where the populations were domesticated and tested (and will not be available in the future, to protect the sanitary status of this country which is free of the main viral shrimp diseases).

Nevertheless, even without knowing which of these two effects accounts for the better performances, our study demonstrates that the shrimp industry in New Caledonia, which was one of the first to rely on an exotic captive stock, may benefit from using two different inbred parental stocks to produce generation $F_{1}$-hybrids for each commercial grow-out. Of course, inbreeding within each parental stock should be managed by using enough parents at each generation in order to maintain their residual genetic variability on a long term basis for sustainability reasons (Goyard et al., 2003). In our case, the strategy tested is efficient in terms of growth rate, and also in terms of survival when conditions are not optimum for the shrimp. The expected increase in production of $P$. stylirostris could be around 85\% (according to our average results) if producers keep stocking their ponds at their current densities using $\mathrm{F}_{1}$-hybrids. This possible increase has to be taken into account to preserve the equilibrium of the pond ecosystem (Herbland, unpublished). For sustainability reasons, it is advisable to stock $F_{1}$-hybrid animals at lower densities, to produce the same biomass using less input.

The strategy tested here with $P$. stylirostris could be valuable with other species used in aquaculture industries which cannot afford large selection programs. This is notably true when only inbred populations are available (as it is the case in some shrimp or fish species), or when introduction of genetic variability from the wild or from other genetic resources represents a zoo-sanitary risk which the producers do not want or are not able to take.

\section{Acknowledgments}

This study was done with Hawaiian and Hybrid animals belonging to the producers' organization UPRAC-NC (under the presidency of R. Bador). The hatchery work to produce the animals used in this study was performed by $\mathrm{F}$. Broutoi and J-R. Mailliez at the Ifremer Research Station of Saint Vincent in New Caledonia. Management of experimental ponds was performed by $\mathrm{C}$. Lambert and E. Pita, tagging and harvesting by most of the staff of Ifremer Research Station. The English language of the manuscript was corrected by E. Walling.

This work was partly supported by grants from the South and North Provinces of New Caledonia and the French Ministry of Research. 
AQUACOP, 1979. Penaeid reared broodstock: closing the cycle of $P$. monodon, $P$. stylirostris and $P$. vannamei. Proc. 10th Ann. Meet. World Aquacult. Soc. 10, 445-452.

AQUACOP, 1983. Constitution of broodstock, maturation, spawning and hatchery system for penaeid shrimps in the Centre Océanologique du Pacifique. In: McVey, J.P. (Ed.), CRC Handbook of Mariculture, vol. 1. Crustacean Aquaculture, CRC Press, Boca Raton, Florida, USA, pp. 105-121.

Argue, B.J., Alcivar-Warren, A., 2000. Genetics and breeding applied to the penaeid shrimp farming industry. In: Bullis, R.A., Pruder, G.D. (Eds.), Controlled and Biosecure Production Systems. Proceedings of a special session integration of shrimp and chicken models. The Oceanic Institute, Waimanalo, Hawaii, USA, pp. 29-54.

Bierne, N., Beuzart, I., Vonau, V., Bonhomme, F., Bédier, E., AQUACOP, 2000. Microsatellite-associated heterosis in hatchery-propagated stocks of the shrimp Penaeus stylirostris. Aquaculture 184, 203-219.

Chim, L., Castex, M., Wabete, N., Lemaire, P., Pham, D., Brun, P., 2007. Development of an original tool for shrimp culture studies using floating cages in earthen pond. First trial carried out to evaluate lacticacid probiotic (Bactocell(B) in shrimp Litopenaeus stylirostris reared in commercial farm subject to vibriosis. World Aquaculture Society, Book of abstracts Asian Pacific Aquaculture 2007, August 5-8 2007, Hanoi, Vietnam; 41.

Clifford., H.C., 1992. Marine shrimp pond management: a review. In: Wvban., J. (Ed.), Proceedings of the special session on shrimp farming, World Aquaculture Society, Baton Rouge, Louisiana, USA, pp. 110-138.

Costa, R., Mermoud, I., Koblavi, S., Morlet, B., Haffner, P., Berthe, F., Le Groumellec, M., Grimont, P., 1998. Isolation and characterization of bacteria associated with a Penaeus stylirostris disease (Syndrome 93) in New Caledonia. Aquaculture 164, 297-309.

Crnokrak, P., Barretta, S.C., 2002. Perspective: purging the genetic load: a review of the experimental evidence. Evolution 56 (12), 2347-2358.

De Freitas, P.D., Junior, P.M.G., 2002. PCR-based VNTR core sequence analysis for inferring genetic diversity in the shrimp Litopenaeus vannamei. Genet. Mol. Biol. 25, 431-434.

De Lorgeril, J., Janech, M., Goarant, C., Goyard, E., Bo, D., Xiang, J., Tassanakajon, A., Somboonwiwat, K., Bachère, E., Piquemal, D., 2004. Analyse of immune gene expression in shrimps: a tool for health monitoring or genetic selection. European Aquaculture Society, Book of abstracts Aquaculture Europe 2004, p.284.

FAO. 2007. FAO FISHSTAT Plus Database (v.2.32).

Gitterle, T., Rye, M., Salte, R., Cock, J., Johansen, H., Suarez, J.A., Lozano, C., Gjerde, B., 2005. Genetic (co)variation in harvest body weight and survival in Penaeus (Litopenaeus) vannamei under standard commercial conditions. Aquaculture 246, 83-92.

Gjedrem, T., 1997. Selective breeding to improve aquaculture production. World Aquaculture 28(1), 33-45.

Gjøen, H.M., Bentsen, H.B., 1997. Past, present, and future of genetic improvement in salmon aquaculture. ICES J. Mar. Sci. 54, 1009-1014.

Goarant, C., Mérien, F., Berthe, F., Mermoud, I., Pérolat, P., 1999. Arbitrarily primed PCR to type Vibrio spp. pathogenic for shrimp. Appl. Environ. Microbiol. 65, 1145-1151.

Goarant, C., Harache, Y., Herbland, A., Mugnier, C., 2004a. Styli 2003 - Trente ans de crevetticulture en NouvelleCalédonie. Nouméa-Koné, 2-6 juin 2003. Ifremer Edition, Actes Colloq. 38, 280 pp.

Goarant, C., Herlin, J., Ansquer, D., Brizard, R., Marteau, A.L., 2004b. Vibrio penaeicida and Syndrome 93 in New Caledonian prawn farming: review and perspectives.. In : Goarant, C., Herbland, A., Harache, Y., Mugnier, C. (Eds.), Styli 2003, Trente ans de crevetticulture en Nouvelle-Calédonie, Ifremer Edition., Actes Colloq. 38, 203-209 (in French with English abstract).

Goarant, C., Ansquer, D., Herlin, J., Domalain, D., Imbert, F., De Decker, S., 2006. Summer Syndrome in Litopenaeus stylirostris in New Caledonia: Pathology and epidemiology of the etiological agent, Vibrio nigripulchritudo. Aquaculture 253, 105-113.

Godin, D.M., Carr, W.H., Hagino, G., Segura, F., Sweeney, J.N., Blankenship, L., 1996. Evaluation of a fluorescent elastomer internal tag in juvenile and adult shrimp, Penaeus vannamei. Aquaculture 139, 243-248.

Goyard, E., Arnaud, S., Vonau, V., Bishoff, V., Mouchel, O., Pham, D., Wyban, J., Boudry, P., Aquacop, 2003. Residual genetic variability in domesticated populations of the Pacific blue shrimp (Litopenaeus stylirostris) of NewCaledonia, French Polynesia and Hawaii and some management recommendations. Aquat. Living Resour. 16, 501508.

Harache, Y., Herbland, A., 2004. Le programme DESANS (Défi Santé Stylirostris): une démarche comparable au Défi

MOREST appliquée à la filière crevette Calédonienne, In: Goarant, C., Herbland, A., Harache, Y., Mugnier, C. (Eds.),

Styli 2003, Trente ans de crevetticulture en Nouvelle-Calédonie, Ifremer Edition, Actes Colloq., 38, 31-38 (in French with English abstract).

Keys, S.J., Crocos, P.J., Burridge, C.Y., Coman, G.J., Davis, G.P., Preston, N.P., 2004. Comparative growth and survival of inbred and outbred Penaeus japonicus, reared under controlled environment conditions: indications of inbreeding depression. Aquaculture 241, 151-168.

Lucien-Brun, H., 2001. Shrimp farming in New Caledonia: successful, integrated industry. Global Aquac. Adv. 4, 6364. 
Lotz, J.M., Browdy, C.L., Carr, W.H., Frelier, P.F., Lightner, D.V., 1995. USMFP suggested procedures and guidelines for assuring the specific pathogen status of shrimp broodstock and seed. In: Browdy, C.L., Hopkins, J.S. (Eds.), Swimming Through Troubled Waters: Proceedings of the special session on shrimp Farming, World Aquaculture Society, Baton Rouge, Louisiana, USA. pp. 66-75.

Mermoud, I., Costa, R., Ferré, O., Goarant, C., Haffner, P., 1998. Syndrome 93 in New Caledonian outdoor rearing ponds of Penaeus stylirostris : history and description of the three major outbreaks. Aquaculture 164, 323-335.

Moss, S.M., 2002. Marine shrimp farming in the western hemisphere: past problems, present solutions, and future visions. Rev. Fish. Sci. 10, 601-620.

Moss, S.M., Moss, D.R, Arce, S.A., Otoshi, C.A., 2005a. Disease prevention strategies for penaeid shrimp culture. In: Pathobiology and Aquaculture of Crustaceans: Proceedings of the 32nd US-Japan Natural Resources Aquaculture Panel, US-Japan Natural Resources Technical Report, 9 pp.

Moss, S.M., Doyle, R.W., Lightner, D.V., 2005b. Breeding shrimp for disease resistance: challenges and opportunities for improvement. In: Walker, P., Lester, R., Bondad-Reantaso, M.G. (Eds.), Diseases in Asian Aquaculture V, Fish Health Section, Asian Fisheries Society, Manila, Philippines. pp. 379-393.

Rosenberry, B., 2006. World shrimp farming. Shrimp news international

Saulnier, D., Haffner, P., Goarant, C., Levy, P., Ansquer, D., 2000a. Experimental infection models for shrimp vibriosis studies: a review. Aquaculture 191, 133-144.

Saulnier, D., Avarre, J.C., Le Moullac, G., Ansquer, D., Levy, P., Vonau, V., 2000b. Rapid and sensitive PCR detection of Vibrio penaeicida, the putative etiological agent of Syndrome 93 in New Caledonia. Dis. Aquatic Org. 40, 109-115.

Sanchez, M.P., Chevassus, B., Labbé, I., Quillet, E., Mambrini, M., 2001. Selection for growth of brown trout (salmo trutta) affects feed intake but not feed efficiency. Aquat. Living Resour. 14(1), 41-48.

Sbordoni,V., deMatthaeis, E., Sbordoni, M.C., La Rosa, G., Mattoccia, M., 1986. Bottleneck effects and the depression of genetic variability in hatchery stocks of Penaeus japonicus (Crustacea, Decapoda). Aquaculture 57, 239-251. 
Table 1. Characteristics of experimental infection challenges (type of infection, number of tagged animals transferred in infection room, survival rates observed)

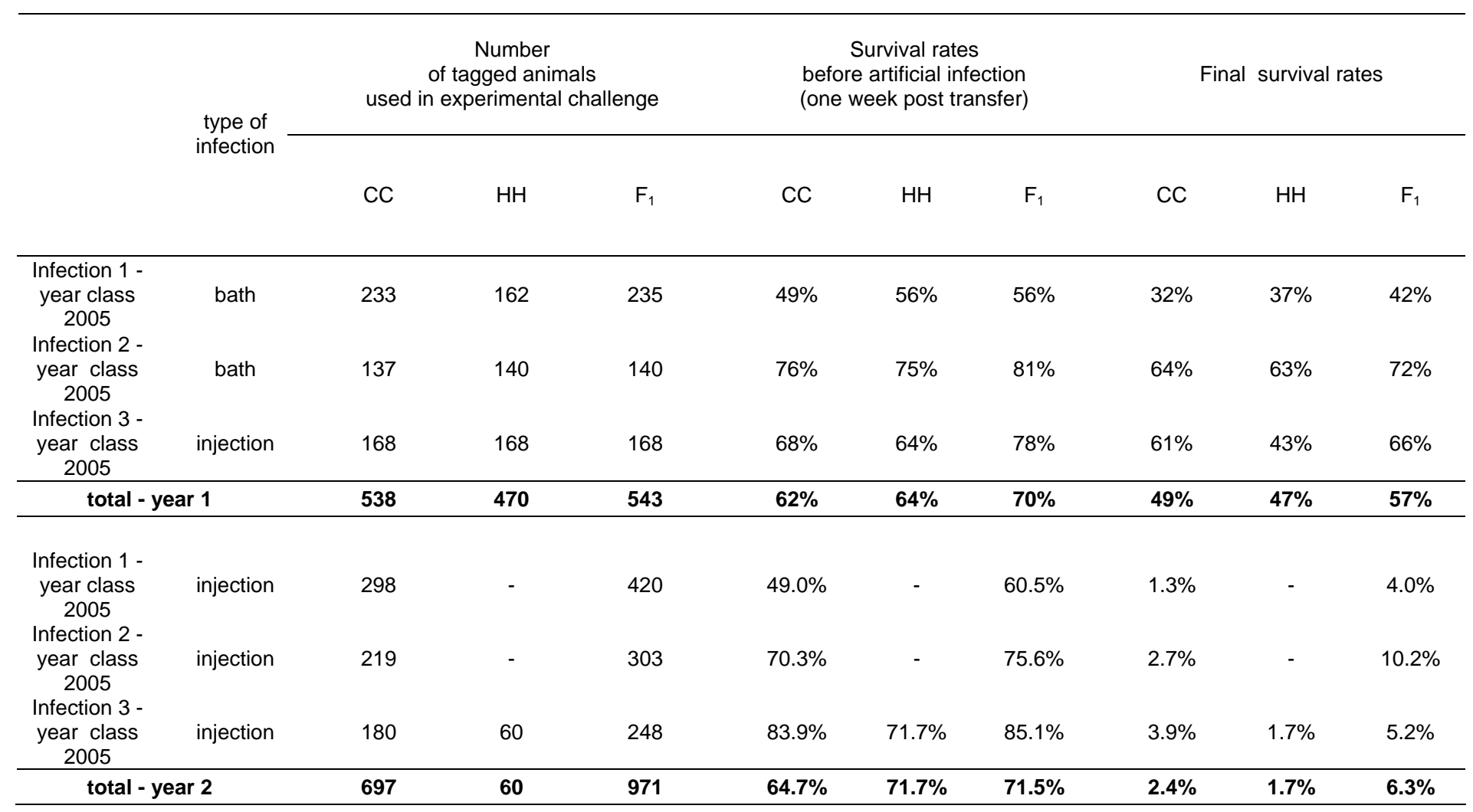

Table 2. Stocking and harvest planning of experimental cages used in a farm affected by $V$. nigripulchritudo

\begin{tabular}{|c|c|c|c|c|c|c|c|}
\hline \multirow[b]{2}{*}{ Type of cages } & \multirow{2}{*}{$\begin{array}{c}\text { Total } \\
\text { number of } \\
\text { cages } \\
\text { stocked }\end{array}$} & \multicolumn{3}{|c|}{ Number of animals per cage } & \multicolumn{3}{|c|}{ Number of cages harvested } \\
\hline & & CC-2006 & $\mathrm{HH}-2006$ & $F_{1}-2006$ & at day 29 & at day 57 & at day 77 \\
\hline $\begin{array}{c}\text { « CC only » } \\
\text { ("separate rearing") }\end{array}$ & 7 & $\begin{array}{c}300 \\
\text { untagged }\end{array}$ & - & - & 2 & 2 & 3 \\
\hline $\begin{array}{c}\text { « } \mathrm{F}_{1} \text { only » } \\
\text { ("separate rearing") }\end{array}$ & 14 & - & - & $\begin{array}{c}300 \\
\text { untagged }\end{array}$ & 4 & 4 & 6 \\
\hline $\begin{array}{l}\text { "Mixed } \mathrm{CC}, \mathrm{HH} \text { and } \mathrm{F}_{1} " \\
\text { ("communal rearing") }\end{array}$ & 9 & $\begin{array}{c}75 \\
\text { tagged }\end{array}$ & $\begin{array}{c}75 \\
\text { tagged }\end{array}$ & $\begin{array}{c}150 \\
\text { tagged }\end{array}$ & 2 & 2 & 5 \\
\hline
\end{tabular}


Table 3. Individual weights at stocking and harvest and average growth rates observed in experimental earthen ponds and in experimental cages where populations were reared, tagged and mixed together ("communal rearing" conditions) or separately ("separate rearing" conditions)

\begin{tabular}{|c|c|c|c|c|c|c|c|c|c|c|c|c|c|c|}
\hline & & \multicolumn{3}{|c|}{$\begin{array}{l}\text { initial weight } \\
\text { at the time of tagging and mixing }(\mathrm{g})\end{array}$} & \multirow{2}{*}{$\begin{array}{l}\text { Time of } \\
\text { harvest }^{1}\end{array}$} & \multicolumn{3}{|c|}{$\begin{array}{l}\text { final weight } \\
\text { (g) }\end{array}$} & \multicolumn{3}{|c|}{$\begin{array}{c}\text { average } \\
\text { growth rate (g/day) }\end{array}$} & \multicolumn{3}{|c|}{$\begin{array}{c}\text { Final } \\
\text { survival rate }^{2}\end{array}$} \\
\hline & & $\mathrm{CC}$ & $\mathrm{HH}$ & $\mathrm{F}_{1}$ & & $\mathrm{CC}$ & $\mathrm{HH}$ & $\mathrm{F}_{1}$ & $\mathrm{CC}$ & $\mathrm{HH}$ & $\mathrm{F}_{1}$ & $\mathrm{CC}$ & $\mathrm{HH}$ & $F_{1}$ \\
\hline \multirow{2}{*}{$\begin{array}{l}\text { Ponds / } \\
\text { year class } \\
2005\end{array}$} & Pond 1 & $\begin{array}{c}3.3 \\
(0.8 \mathrm{SD})\end{array}$ & $\begin{array}{c}3.4 \\
(1.3 \mathrm{SD})\end{array}$ & $\begin{array}{c}2.9 \\
(0.4 \mathrm{SD})\end{array}$ & 134 & $\begin{array}{c}25.5 \\
(3.3 \mathrm{SD})\end{array}$ & $\begin{array}{c}26.6 \\
(2.5 \mathrm{SD})\end{array}$ & $\begin{array}{c}32.3 \\
(3.0 \mathrm{SD})\end{array}$ & 0.17 & 0.17 & 0.22 & $52 \%$ & $60 \%$ & $61 \%$ \\
\hline & Pond 2 & $\begin{array}{c}3.3 \\
(0.8 \mathrm{SD})\end{array}$ & $\begin{array}{c}3.4 \\
(1.3 \mathrm{SD})\end{array}$ & $\begin{array}{c}2.9 \\
(0.4 \mathrm{SD})\end{array}$ & 134 & $\begin{array}{c}24.0 \\
(2.8 \mathrm{SD})\end{array}$ & $\begin{array}{c}24.5 \\
(2.3 \mathrm{SD})\end{array}$ & $\begin{array}{c}30.4 \\
(3.1 \mathrm{SD})\end{array}$ & 0.15 & 0.16 & 0.21 & $50 \%$ & $60 \%$ & $60 \%$ \\
\hline \multirow{2}{*}{$\begin{array}{c}\text { Ponds / } \\
\text { year class } \\
2006\end{array}$} & Pond 1 & $\begin{array}{c}4.0 \\
(1.2 \mathrm{SD})\end{array}$ & $\begin{array}{c}11.1 \\
(2.9 \mathrm{SD})\end{array}$ & $\begin{array}{c}3.8 \\
(1.2 \mathrm{SD})\end{array}$ & 126 & $\begin{array}{c}25.5 \\
(3.7 \mathrm{SD})\end{array}$ & $\begin{array}{c}31.2 \\
(5.0 \mathrm{SD})\end{array}$ & $\begin{array}{c}33.3 \\
(3.2 \mathrm{SD})\end{array}$ & 0.17 & 0.16 & 0.23 & $37 \%$ & $27 \%$ & $55 \%$ \\
\hline & Pond 2 & $\begin{array}{c}4.0 \\
(1.2 \mathrm{SD})\end{array}$ & $\begin{array}{c}11.1 \\
(2.9 \mathrm{SD})\end{array}$ & $\begin{array}{l}3.8 \\
(1.2 \mathrm{SD})\end{array}$ & 126 & $\begin{array}{c}26.0 \\
(4.3 \mathrm{SD})\end{array}$ & $\begin{array}{c}32.8 \\
(4.3 \mathrm{SD})\end{array}$ & $\begin{array}{c}35.2 \\
(3.7 \mathrm{SD})\end{array}$ & 0.17 & 0.17 & 0.25 & $32 \%$ & $38 \%$ & $52 \%$ \\
\hline \multirow{2}{*}{$\begin{array}{c}\text { Cages / } \\
\text { year class } \\
2006\end{array}$} & $\begin{array}{c}\text { "Separate } \\
\text { rearing" } \\
\text { cages }\end{array}$ & $\begin{array}{l}3.1 \\
(1.1 \mathrm{SD})\end{array}$ & - & $\begin{array}{l}3.1 \\
(1.0 \mathrm{SD})\end{array}$ & 77 & $\begin{array}{c}16.2 \\
(3.0 \mathrm{SD})\end{array}$ & - & $\begin{array}{c}23.3 \\
(3.3 \mathrm{SD})\end{array}$ & 0.17 & - & 0.26 & $38 \%$ & - & $51 \%$ \\
\hline & $\begin{array}{l}\text { "Communal } \\
\text { rearing" } \\
\text { cages }\end{array}$ & $\begin{array}{l}3.1 \\
(1.1 \mathrm{SD})\end{array}$ & $\begin{array}{c}9.7 \\
(1.6 \mathrm{SD})\end{array}$ & $\begin{array}{c}3.1 \\
(1.0 \mathrm{SD})\end{array}$ & 77 & $\begin{array}{c}17.7 \\
(3.6 \mathrm{SD})\end{array}$ & $\begin{array}{c}24.0 \\
(3.7 \mathrm{SD})\end{array}$ & $\begin{array}{c}24.4 \\
(2.7 \mathrm{SD})\end{array}$ & 0.19 & 0.19 & 0.28 & $44 \%$ & $40 \%$ & $52 \%$ \\
\hline
\end{tabular}

${ }^{1}$ Days post stocking; ${ }^{2}$ From stocking to harvest

Table 4. V. nigripulchritudo prevalence and $V$. nigripulchritudo haemolymph concentration (number of presumed $V$. nigripulchritudo colonies per 10-microliter of haemolymph) observed in cages at three different times (D29, D57, D77).

\begin{tabular}{|c|c|c|c|c|c|c|c|c|c|}
\hline & \multicolumn{3}{|c|}{ Results at D29 } & \multicolumn{3}{|c|}{ Results at D57 } & \multicolumn{3}{|c|}{ Results at D77 } \\
\hline & CC-2006 & $\mathrm{HH}-2006$ & $F_{1}-2006$ & CC-2006 & $\mathrm{HH}-2006$ & $F_{1}-2006$ & CC-2006 & HH-2006 & $F_{1}-2006$ \\
\hline $\begin{array}{l}\text { Number of animals } \\
\text { sampled }\end{array}$ & 30 & 30 & 30 & 30 & 30 & 30 & 30 & 30 & 30 \\
\hline Prevalence & $93 \%$ & $100 \%$ & $93 \%$ & $63 \%$ & $43 \%$ & $47 \%$ & $53 \%$ & $50 \%$ & $73 \%$ \\
\hline \multicolumn{10}{|l|}{$\begin{array}{l}\text { Class of } V \text {. } \\
\text { nigripulchritudo load }\end{array}$} \\
\hline 0 & $7 \%$ & $0 \%$ & $7 \%$ & $37 \%$ & $57 \%$ & $53 \%$ & $47 \%$ & $50 \%$ & $27 \%$ \\
\hline $1-10$ & $20 \%$ & $43 \%$ & $40 \%$ & $57 \%$ & $43 \%$ & $43 \%$ & $47 \%$ & $50 \%$ & $63 \%$ \\
\hline $11-50$ & $10 \%$ & $43 \%$ & $40 \%$ & $7 \%$ & $0 \%$ & $3 \%$ & $7 \%$ & $0 \%$ & $10 \%$ \\
\hline $51-100$ & $3 \%$ & $0 \%$ & $3 \%$ & $0 \%$ & $0 \%$ & $0 \%$ & $0 \%$ & $0 \%$ & $0 \%$ \\
\hline $101-300$ & $10 \%$ & $3 \%$ & $3 \%$ & $0 \%$ & $0 \%$ & $0 \%$ & $0 \%$ & $0 \%$ & $0 \%$ \\
\hline$>300$ & $50 \%$ & $10 \%$ & $7 \%$ & $0 \%$ & $0 \%$ & $0 \%$ & $0 \%$ & $0 \%$ & $0 \%$ \\
\hline
\end{tabular}




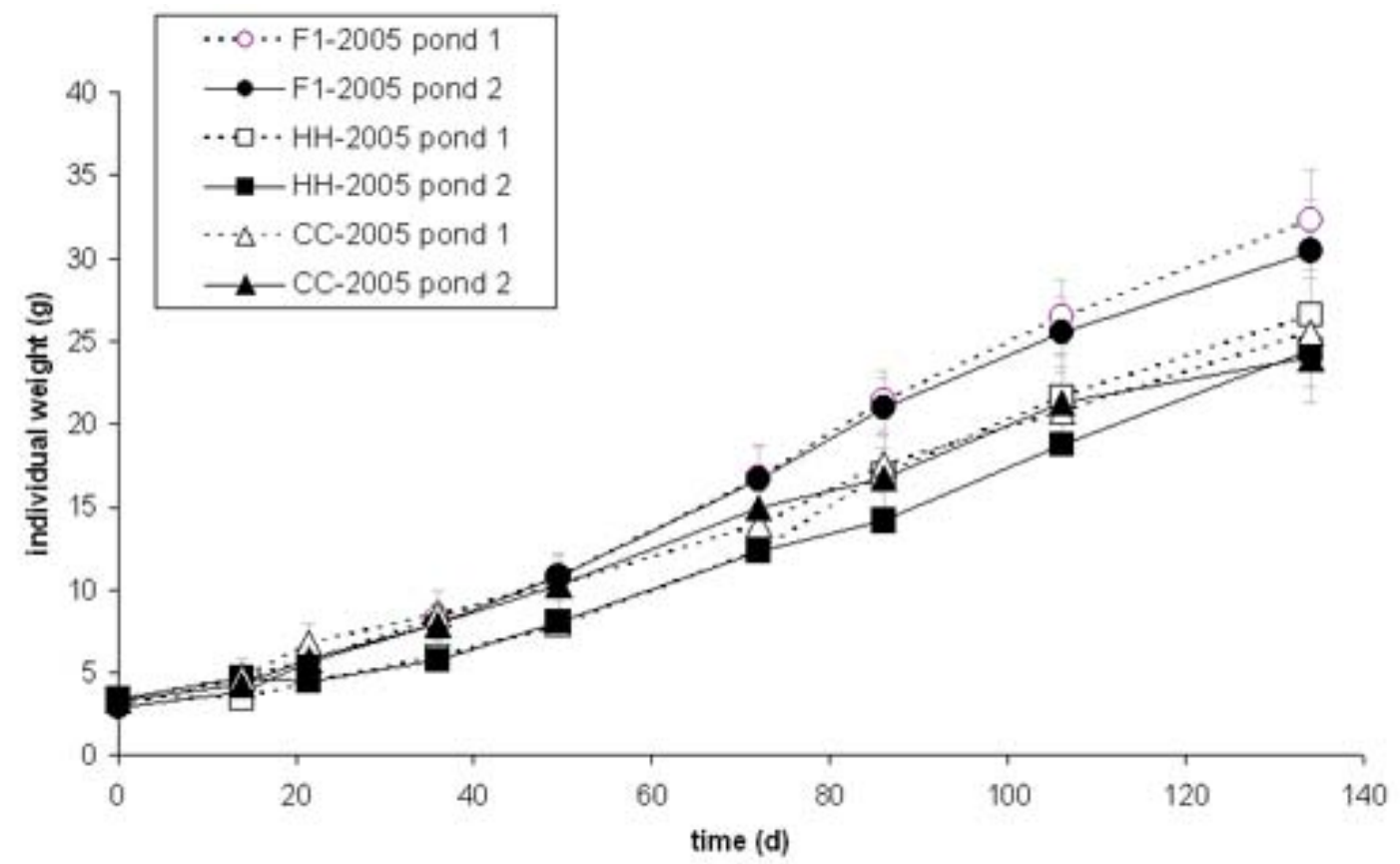

Fig. 1a. Growth observed in the three populations studied ("pure Hawaiian" HH-2005, "pure Caledonian" CC-2005 and " $F_{1}$ Hybrid" $\left.F_{1}-2005\right)$ in two $500 \mathrm{~m}^{2}$ earthen ponds in 2006.

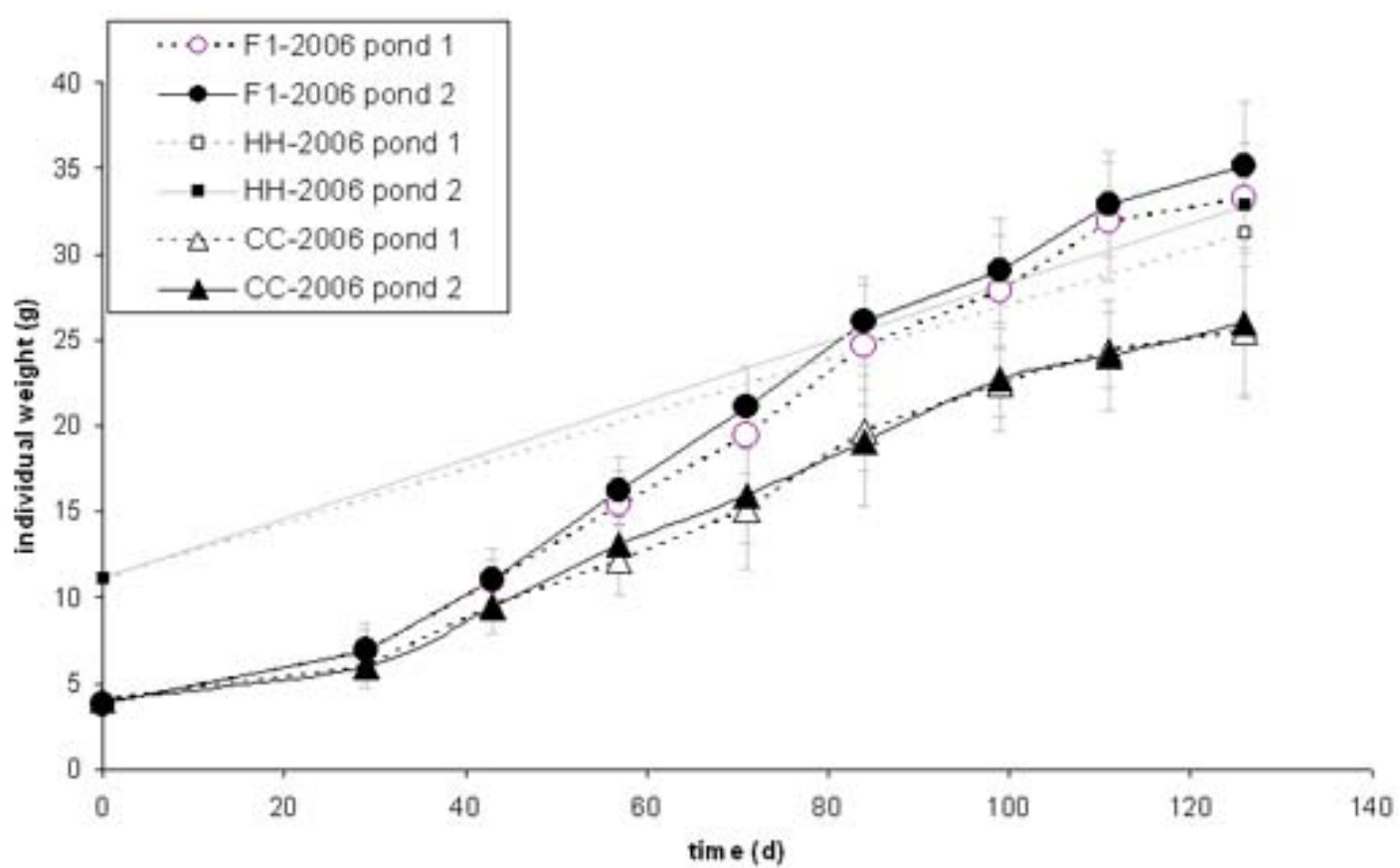

Fig. 1b. Growth observed in the three populations studied ("pure Hawaiian" HH-2006, "pure Caledonian" CC-2006 and " $F_{1}$ Hybrid" $F_{1}-2006$ ) in two 500m2 earthen ponds in 2007. NB : Because the Hawaiian population had had a non typical pre-growing period before tagging and mixing (inducing poor survival and rapid growth), this population was stocked but not followed until the final harvest. 


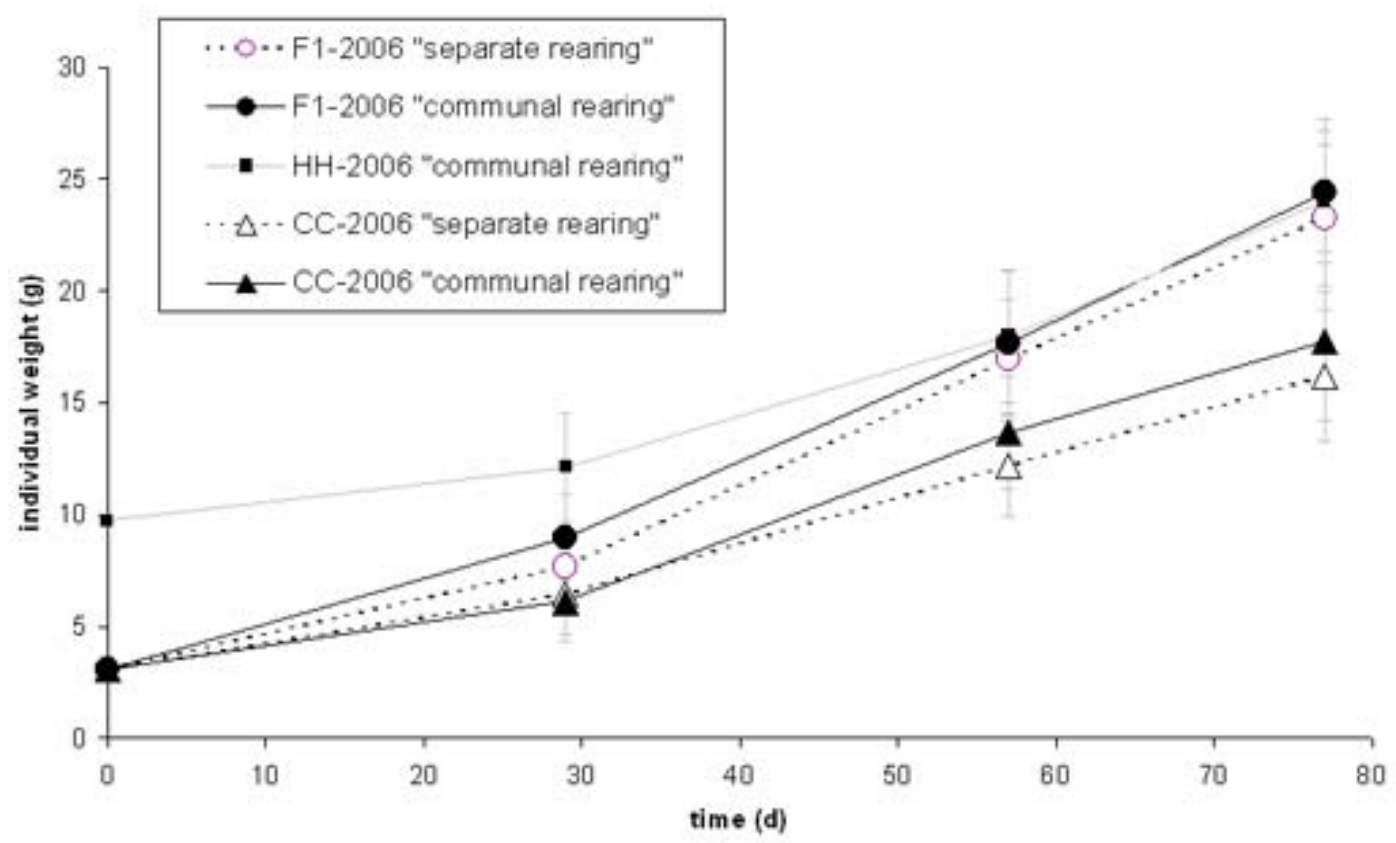

Fig. 2a. Growth observed in the three populations studied ("pure Hawaiian" HH-2006, "pure Caledonian" CC-2006 and " $F_{1}$ Hybrid" $F_{1}-2006$ ) in floating cages where they were reared in "communal rearing" conditions (tagged and mixed together) or in "separate rearing" conditions (reared in separate cages at the same density).

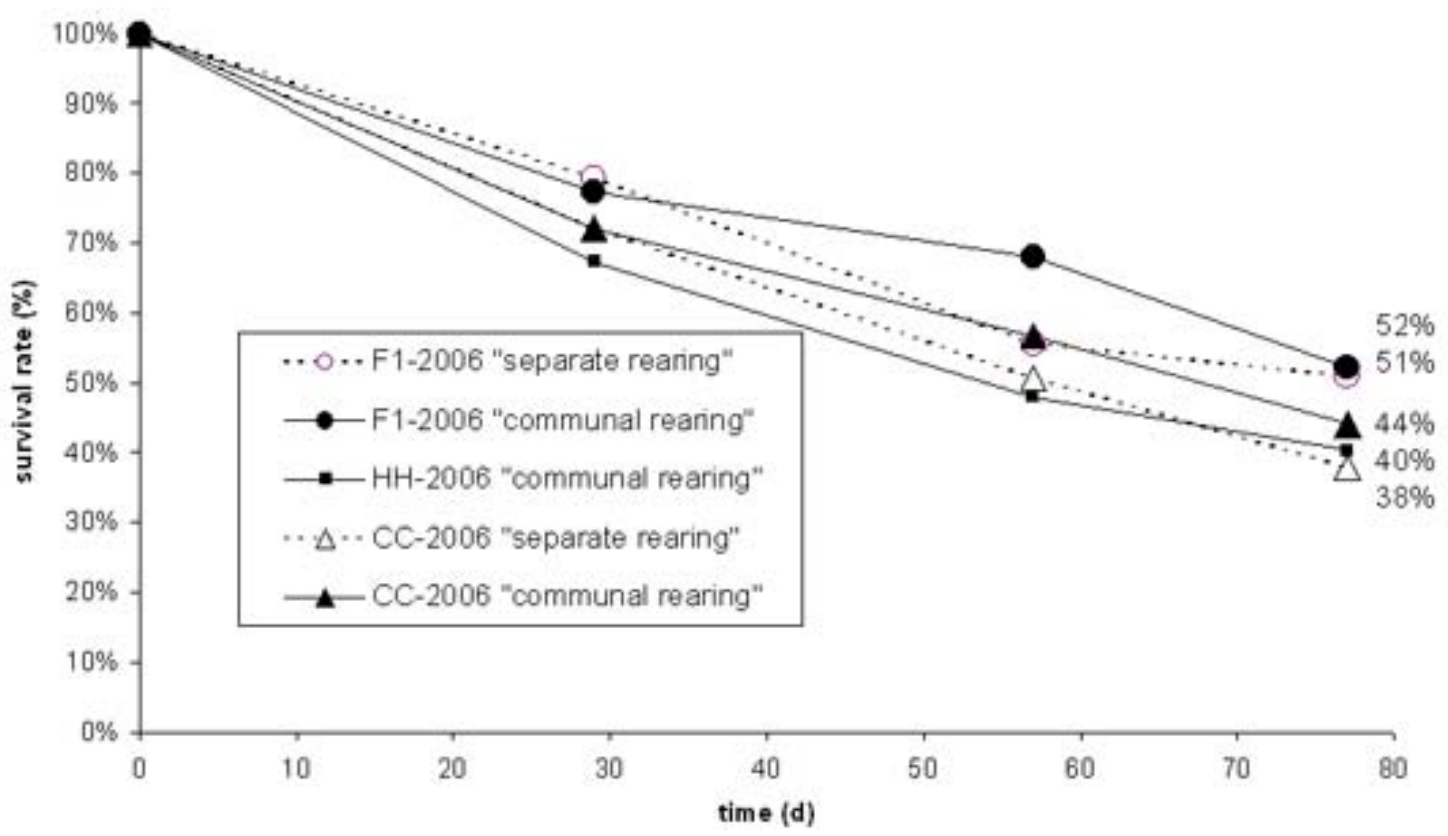

Fig. 2b. Survival rates observed in the three populations studied ("pure Hawaiian" HH-2006, "pure Caledonian" CC2006 and " $F_{1}$ Hybrid" $F_{1}-2006$ ) in floating cages where they were reared in "communal rearing" conditions (tagged and mixed together) or in "separate rearing" conditions (reared in separate cages at the same density). 


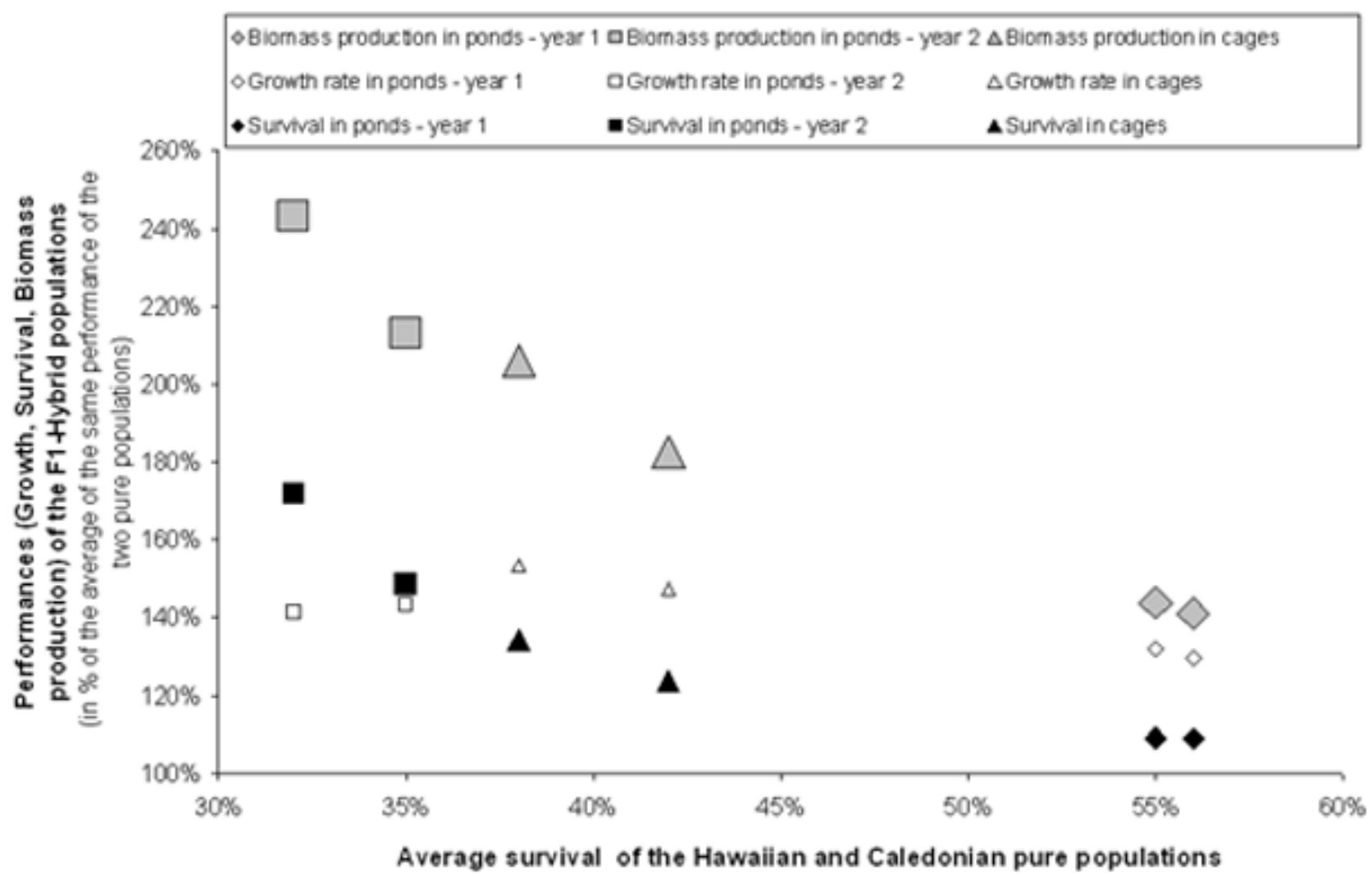

Fig. 3. Growth rates, survival rates and biomass production of $F_{1}$-hybrid populations observed in ponds and cages, and expressed in percentage of the ones of the two pure Hawaiian and New Caledonian populations and plotted in function of the average survival rates observed in the two pure populations. 